Article

\title{
Market-Based Housing Reforms and the Residualization of Public Housing: The Experience of Lodz, Poland
}

\author{
Agnieszka Ogrodowczyk ${ }^{1, *}$ and Szymon Marcińczak ${ }^{2}$ \\ ${ }^{1}$ Institute of the Built Environment and Spatial Policy, University of Lodz, 90-142 Lodz, Poland; \\ E-Mail: agnieszka.ogrodowczyk@geo.uni.lodz.pl \\ 2 Institute of Urban Geography, Tourism Studies and Geoinformation, University of Lodz, 90-142 Lodz, Poland; \\ E-Mail: szymon.marcinczak@geo.uni.lodz.pl \\ * Corresponding author
}

Submitted: 14 November 2020 | Accepted: 7 April 2021 | Published: 13 May 2021

\begin{abstract}
Housing inequality is one of the central topics in urban studies, and in the social sciences more broadly. It is also one of the most significant and visible aspects of socioeconomic inequality. Over the last three decades, the process of housing commodification has accelerated across western societies and, consequently, the public housing sector has contracted and become more closely associated with the poorest sections of societies in many cities. Over the same period, the political changes in Central and Eastern Europe have contributed to the dismantling and monetizing of state housing sectors at the forefront of broader social and economic transformations. Unfortunately, most recent studies on housing commodification and inequalities in Europe are confined to the national scale. The aim of this article is to detail the linkages between the position and functioning of public housing in Lodz (Poland) and the evolving socioeconomic profile of individuals and households that rely on public housing. This study relies on microdata (statistical information on individuals and households) from two national Polish censuses (1978 and 2002) and from household budget surveys (2003-2013). The main finding of our study is that 'residualization' is present in the public housing stock in Lodz and that the process gained momentum in the first decade of the 2000s.
\end{abstract}

\section{Keywords}

housing inequalities; housing reforms; Lodz; Poland; public housing; residualization

Issue

This article is part of the issue "Vicious Circle of Segregation: Understanding the Connectedness of Spatial Inequality across Generations and Life Domains" edited by Tiit Tammaru (University of Tartu, Estonia), Siiri Silm (University of Tartu, Estonia), Frank Witlox (Ghent University, Belgium), Maarten van Ham (Delft University of Technology, The Netherlands) and Madli-Johanna Maidla (University of Tartu, Estonia).

(C) 2021 by the authors; licensee Cogitatio (Lisbon, Portugal). This article is licensed under a Creative Commons Attribution 4.0 International License (CC BY).

\section{Introduction}

Housing inequality is one of the central topics in urban studies and in the social sciences more broadly. It is also one of the most significant and visible aspects of social (socioeconomic) inequality. Welfare and housing regimes play an important role in mediating the effects of social inequalities and the changing urban landscape in Europe. While state interventions in Europe have long countered socioeconomic disparities, (neo) liberal transformations in welfare states and housing systems, under the influence of globalization, changed this trend. Accordingly, for the last thirty years income inequalities in Europe have been on the rise, especially in Eastern Europe (Blanchet, Chancel, \& Gethin, 2019), and cities in Europe have become more socially unequal and spatially divided (Marcińczak, Musterd, van Ham, \& Tammaru, 2016). Regarding the nexus between the proliferation of neo-liberal policies and practices and the housing sector, scholarly attention has centered on 
the process of accelerated marketization of housing provision and consumption across western societies, and on how housing commodification contributes to increasing disparities along racial or socioeconomic lines (Kadi \& Ronald, 2014; Madden \& Marcuse, 2016). In a similar vein, there are arguments that the roll-back of the welfare state together with the marketization of public services triggered the process of 'residualization' of the public housing sector (Musterd, 2014). This form of housing generally relates to those types of housing provision which involve elements of decommodification and not-for profit, some bureaucratic process of allocation, and where access is not determined by ability to pay a market price or rent. The process of residualization implies that public housing sectors have contracted and become more closely associated with the poorest sections of societies-areas where public housing dominates are often spatially marginalized and more socially stigmatized (Forrest, 2014). Importantly, although the current understanding of the term residualization highlights the more recent effects of marketization and neo-liberal reforms to the welfare system on the declining shares of public housing, the decreasing social status of this tenure form appears to pre-date the era of extensive privatization. The results from the UK suggest that the increase in unemployed and lower social class households in public sector housing was already evident when public housing was still expanding (Forrest \& Murie, 1983; Williams, Sewel, \& Twine, 1988). The large-scale privatization that started in the 1980 s simply gave momentum to the process, and residualization was sensitive to differentiation within the public housing stock (Murie, 1997). Put differently, there are grounds to assume that residualization, the declining social status of public housing in particular, could be selective and not solely related to privatization.

In Western Europe, direct state housing provision is often represented as a failed social intervention and symptomatic of the malaise of welfare dependency (Forrest, 2014). At the same time, housing studies have convincingly demonstrated that the transformation of public housing follows different trajectories in different countries and is crucially affected by the "housing systems' it refers to (for an overview see Kemeny, 1995; Stephens, Lux, \& Sunega, 2015). Then, while market-based transformations of the housing sector have become a fairly ubiquitous process, they are embedded in, and premised upon, pre-existing institutional structures, making reforms and their social and spatial effects highly contingent on local economic, political and demographic contexts (Brenner, Peck, \& Theodore, 2010).

With some delay compared to Western Europe, the political changes in Central and Eastern Europe (CEE) and the region's re-emergence into the world economy have seen the dismantling and monetizing of state housing sectors at the forefront of broader social and economic transformations (Lux \& Sunega, 2014). As space precludes a comprehensive review of literature on hous- ing transition after socialism-for recent reviews and explanations see Hegedus, Lux, and Teller (2013), Soaita and Dewilde (2020) and Stephens et al. (2015)-suffice it to say that, characterized by the decommodified housing system before 1990, the CEE countries implemented a large-scale give-away privatization of public stock after the collapse of the ancient regime. Essentially, stateowned housing was privatized to sitting tenants at prices substantially below market value. Treating housing privatization as a policy to mitigate the hardship faced by the population during the early economic transition (Hegedus \& Tosics, 1998; Struyk, 1996), the former socialist states eventually moved towards a hyper-ownership model. The differences in skills and education levels gave rise to a rapid increase in income inequality after socialism. Assuming that housing is a key component of household wealth (Benjamin, Chinloy, \& Jud, 2004), the privatization of public housing directly and significantly contributed to the ensuing increase in wealth inequality in the region after 1990. Accordingly, those stuck in public housing have arguably accumulated less wealth than those that benefited from give-away privatization. The effect of housing privatization may also linger to influence the housing opportunities of younger generations, as financial (or in-kind) support from families is among the important factors paving the way to home ownership in the former socialist countries (Criman, 2008).

The scale of housing privatization was not uniform across CEE. Irrespective of the general trend, the housing privatization process has been path-dependent (co-determined by a variety of socialist legacies) and hinged on specific policies adopted and implemented in different national contexts after 1990 (Stephens et al., 2015). There are also grounds to assume that the pace and scale of public housing residualization could differ from city to city. As the history, institutional milieu, structure of the housing stock, functional specialization, and location in a national urban hierarchy are important factors shaping the changes in the socio-spatial structure of the post-socialist city (Marcińczak, Musterd, \& Stępniak, 2012), one can reasonably assume that those characteristics of urban areas should also set the stage for the development of housing stratification after socialism. Such reasoning finds support in the notions of the 'privatization trap' and the 'paradox of decentralization' advanced by Lux and Sunega (2014) to explain the process of residualization of public housing in the former socialist countries. The notion of the privatization trap means that the main tendency in the CEE is to sell existing public housing and that the development of new public housing often assumes privatization in the future (Lux \& Sunega, 2014). Even if the process of giveaway privatization was a common trend across CEE and the resultant privatization trap precluded chances for a sustainable development of public housing after socialism, some countries preserved more of the socialist era public housing - notably the Czech Republic and Poland, where the decision to privatize was shifted down to local 
municipalities (Hegedus et al., 2013). While the privatization trap undeniably triggered the process of public housing residualization, the decentralization paradox gave it a local flavor. In fact, the municipalities that often did not have sufficient resources were faced with the problem of maintaining significant housing stock after 1990. Accordingly, the pace and scale of public housing commodification most likely hinged on the economic condition of municipalities and the residents' interest in the privatization process.

Even though there is wide agreement among urban researchers on both sides of the former Iron Curtain that housing inequalities are on the rise and that the public housing sector is contracting in Europe, existing empirical studies on the relationship between housing commodification and income stratification are limited in two ways. First, the available studies mostly revolve around cross country comparisons of evolving housing policies or focus on the relationship between housing inequalities and income stratification at the national level, thus leaving the local context unexplored-a good example being the recent cross-sectional or longitudinal analyses by Lux, Sunega, and Katrňák (2011), Norris and Winston (2012), and Soaita and Dewilde (2019, 2020). Second, those studies that attempt to link the evolution of the welfare state and housing regime with housing stratification in a specific urban context often adopt a short timeframe for concrete empirical analysis (e.g., Musterd, 2014). Concerning the former socialist countries, it seems that the issue of housing change remains outside the mainstream scholarly debate on post-socialist cities (Stephens et al., 2015), and that most empirical studies on public housing residualization and housing stratification more broadly in specific urban contexts are confined to the first decade of post-socialist transition (Gentile \& Marcińczak, 2014; Hess, Tammaru, \& Leetmaa, 2012). Finally, it is often assumed that the residualization of public housing in the former socialist countries started no sooner than in the 1990s, along with the post-socialist transition.

With this in mind, and based on the assumption that the effects of housing commodification are conditioned by diverse regulatory frameworks and policies, the aim of this article is to explore how the process of residualization manifests itself and what effects it causes in a former socialist city. It thus combines an empirical study of public housing residualization at the city-scale with an analysis of housing reforms adopted and implemented in the multi-scalar environment (national and local). We draw empirical evidence from Lodz, Poland. Importantly, Poland has the highest rate of income inequality in Europe (Blanchet et al., 2019), and it is also tempting to explore how the substantial increase in income disparities relates to the process of public housing commodification after socialism. The study relies on the microdata from national censuses $(1978,2002)$ and household budget surveys (HBSs) from 2003 to 2013. We ask the following research questions:
1. What are the effects of market-based transformations on the position and wider functioning of public housing in Lodz?

2. What are the local housing outcomes of the residualization process-for whom (at the household level) is the public rented sector currently functioning, and has this changed over the last three decades?

The article is structured as follows: The next section presents the evolution of the public housing sector in Poland and in Lodz after socialism in the wider context of housing transitions in CEE. Data and methods are presented in the following section, followed by the empirical findings. Finally, we summarize our conclusions and make some suggestions for future research on housing inequalities in CEE.

\section{Public Housing in Transition: Poland and Lodz}

Far-reaching transformation of the housing sector occurred in CEE in the early 1990s: The transfer of the ownership of properties to individuals or non-state sector organizations has been seen as pivotal to more fundamental processes of social and economic change (Turner, Hegedus, \& Tosics, 1992). In this context, one of the basic problems confronting the transitional economies of CEE has been the lack of a functioning housing market (Forrest \& Williams, 2001). At the beginning of political and economic transformation in Poland, in 1989-1990, housing policy was based on the principle that the purchase or construction of a flat as a property would be the main route to obtaining it.

The housing reforms implemented in the 1990s involved the withdrawal of the State from the financing of housing construction, the communalization of flats belonging to the State and state-owned companies, the abolition of the monopoly of cooperatives in housing construction, the creation of Housing Associations, the introduction of housing allowances for low income households, and the creation of new forms of financing of housing construction (Milewska \& Ogrodowczyk, 2006; Uchman \& Adamski, 2003). Currently, the central government does not participate directly in the housing development process; according to the Local Government Act of 1990 reinstating local government in Poland, housing development is a responsibility of local government (Republic of Poland, 1990). That means that that municipal-led housing development depends on the type of commune, its population size, and its own revenues (e.g., its share of state budget tax revenues or local taxes and fees). The responsibilities of local government in the housing domain (in satisfying the housing needs of the population living on its territory, especially those who are worse-off) include the provision of social and replacement housing and the payment of housing allowances. Municipalities also have some instruments to conduct housing policy. It should be mentioned that 
like in the other CEE countries the acquisition of housing resources (often in poor physical condition) by municipalities in 1990 proved to be a large financial burden for them. This is reflected in the small scale of activities aimed at improving the physical condition of municipal housing stock. Unlike in most other post-socialist countries, and in a similar manner to the Czech Republic (Stephens et al., 2015), municipalities in Poland conduct their own privatization policy with regard to municipal properties. The main motive to privatize public housing was to solve the problem of the maintenance and renovation of municipal buildings. Many experts also believed that the right to buy occupied apartments with a significant discount, give-away privatization, would be a kind of compensation for years spent in an undemocratic and non-market system. Table 1 presents the key policies and regulations implemented in Poland and in Lodz to deal with the issue of public housing.

There were nearly two million flats in the municipal housing stock in Poland in 1990, which constituted $16.7 \%$ of the entire housing stock; the number of dwellings dropped to 868.5 thousand ( $6.1 \%$ of the total stock) in 2016. The reasons for this were: privatization of flats, shutdowns due to the poor physical condition of the housing and the slow pace of construction of new public housing. The last factor was common to virtually all the former socialist countries (Lux \& Sunega, 2014). For instance, the public housing built in 2016 was only $1.3 \%$ of total housing built in Poland that year; the queue of people waiting to rent a flat from the municipal housing stock swelled to nearly 160000 people in 2016. But there was also a setback in the construction of cooperative housing, a sector that was strongly supported by the state in the socialist period. Eventually, private developers have become the main providers of new housing, especially in larger cities.

The contemporary housing structure in Lodz is primarily the result of many complex economic and social processes, which, operating for several centuries (especially in the 19th and 20th centuries), significantly transformed its constituent parts. After the Second World War, inefficient housing policy resulted in an inadequate development of municipal housing in Lodz and led to a significant degradation of the pre-socialist housing stock. In fact, the authorities deliberately did not renovate or modernize the fabric of the historical core, leaving it to dilapidate for nearly fifty years. New public housing developments were mainly carried out to provide substitute accommodation to persons evicted from buildings intended for demolition and only satisfied the housing needs of society to a small extent (Ogrodowczyk, 2015). As was the case elsewhere in Poland in the 1970s and 1980s (Ciechocińska, 1987), the housing needs of the socialist 'middle class' were primarily satisfied by statecontrolled housing cooperatives.

Following the collapse of socialism, the city suffered from the main economic depression that lasted throughout the 1990s, which in turn contributed to huge

Table 1. Public housing related policies and regulations adopted in Poland and Lodz after 1990.

\begin{tabular}{lll}
\hline Years & Poland & Lodz \\
\hline 1990-1994 & The Local Government Act (Ustawa o & First attempts to privatize extensive public \\
Early political and & samorzqdzie gminnym) from 1990. Formerly & housing stock, including the “Own Apartment" \\
socio-economic & state-owned housing stock was transferred to & program (własne mieszkanie) from 1991 to 1997. \\
transition & $\begin{array}{l}\text { municipalities. Municipalities are responsible for } \\
\text { the provision of social housing and for meeting } \\
\text { the housing needs of low-income households. }\end{array}$ & $\begin{array}{l}\text { Housing was privatized to sitting tenants with } \\
\text { discount. }\end{array}$
\end{tabular}

1995-2003

Late transition

An Act from 1997 on the management of real estate regulates the process of privatization. Municipalities set the details of privatization, including the rate of discount that ranges from $1 \%$ to $99 \%$ of the actual property value.

Since 2004

Poland in the

European Union
According to the Municipal Council Act from 1998, sitting tenants were offered the following discount rates:

- 80\% for housing constructed from 1986 to 1996 - 90\% for housing constructed before 1986

The 2012 Lodz Housing Policy 2020+ (Polityka mieszkaniowa Łodzi 2020+) reformed the issue of privatization. Since 2015, the municipality of Lodz has stopped the sale of apartments in buildings that are completely owned by local authorities. On the other hand, privatization has been promoted in those buildings where the share of public stock is less than $25 \%$. The following discount rates have been adopted:

- 70\% for housing constructed before 1946

- 40\% for housing constructed from 1946 to 1989

- 30\% for housing constructed after 1990 
unemployment, growing social problems, and massive population shrinkage; all factors which brought about the devastation of the historical core. Moreover, along with the reform of the country's economic system, Lodz had already taken over 133,000 dwellings from the State Treasury in 1990, and thus became the largest owner of tenement housing among Polish cities. In consequence, the municipality became an owner of housing stock that quite often had (and still has) unresolved issues with property rights. This in turn has brought about substantial difficulties in establishing the legal status of many buildings and plots after 1990, and thus precluded a swift privatization process. Due to the large size of the municipal housing stock and long-term negligence in maintaining its physical condition under socialism, the stateowned buildings, especially those located in the inner city, deteriorated significantly. Unfortunately, the spatial and housing policy after the downfall of socialism did not contribute to the improvement of the physical condition of the tenements in the city centre. Regarding Lodz, almost $70 \%$ of the buildings owned by the municipality in the inner-city are in a bad or very bad physical condition, which does not improve the image of the city-center (Ogrodowczyk, 2014). Housing policy was often carried out on the basis of old documents, updated only in terms of the rental policy and the sale of public housing. This has resulted in an accumulation of the following problems (City Hall of Lodz, 2012): excessive municipal housing stock and its misuse; a lack of social and temporary housing; poor physical condition of the municipal housing stock and its progressive deterioration; low rents in the municipal stock, which limits the possibility of doing repairs or improving quality; rent arrears and the lack of an effective system of debt recovery; an inefficient model for privatization of the housing stock; and lack of land-use plans for a large part of the city, including areas with a high proportion of municipal housing stock, which prevents effective management.

According to the data available from the Central Statistical Office and the Town Hall, from 1999 to 2013 the municipality of Lodz sold almost 33,000 apartments to tenants. It should be emphasized that Lodz is currently pursuing the most active policy of privatization of housing resources among Polish cities. Consequently, the share of municipal housing stock was already declining in the 1990 s: from $38.0 \%$ in 1990 to $28.6 \%$ in 1995 . The process continued in the next decade and public housing constituted only $9.63 \%$ of total stock in 2013 . The location of public housing in Lodz is presented in Figure 1. However, the position of the public sector in housing provision in Lodz was greater than in other major cities such as Warsaw, Kraków, or Poznań, where the share of this

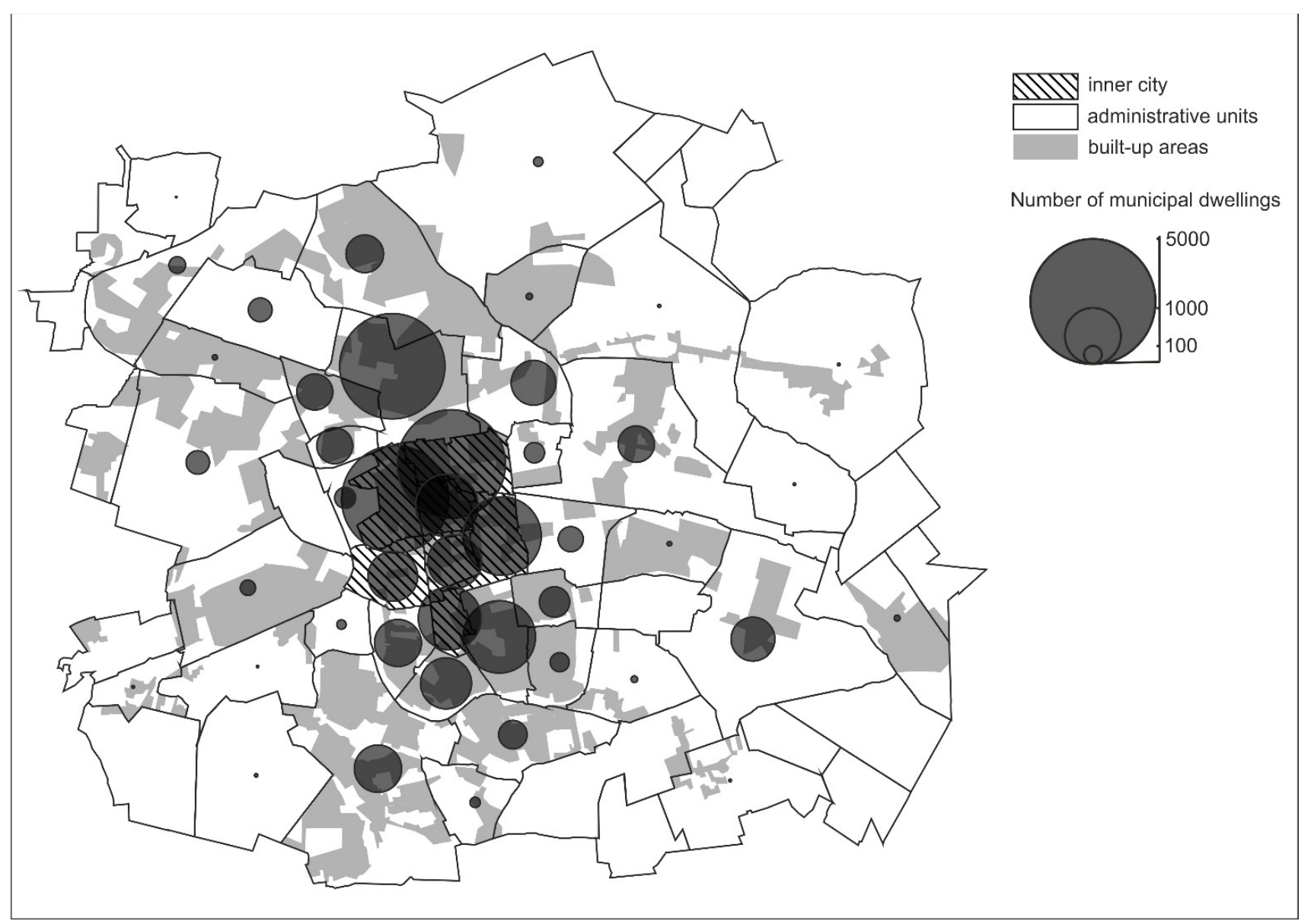

Figure 1. Location of public housing stock in Lodz in 2002. Source: Authors. 
form of tenure was $5.15 \%, 2.68 \%, 3.35 \%$, respectively. To sum up, even if municipalities have been responsible for the process of privatization of public stock in Poland, the main result in Lodz has been the massive transfer of wealth to sitting tenants. However, the process has been spatially selective and determined by differences in the quality of state-owned housing. The process has also had an unequal effect on the distribution of wealth. Those who occupied better quality public housing under socialism benefited the most from the process; paying a fraction of market price, they became the owners of housing that could either be transferred to a family member or commodified with substantial profit.

\section{Data and Methods}

This article relies on microdata (anonymized statistical information on individuals and households) from two main sources: national Polish censuses and HBSs. Regarding the former, we use the $10 \%$ samples from the 1978 and 2002 national censuses that are publicly available from IPUMS (Minnesota Population Center, 2020); these are two large datasets (with more than 20,000 households each) that provide detailed information on the demographic, social, and economic characteristics of individuals and households and on the quality and structure of housing stock in Lodz in 1978 and in 2002. The data enables us to investigate and directly compare the demographic and socioeconomic profiles of residents in public housing at two specific time points. The $10 \%$ sample of census data is fully representative for the population of Lodz. The statistical information for 1978 generally illustrates the socialist system in Poland at the peak of its economic development, especially in terms of housing production. The postsocialist systemic transition was virtually finished in 2002, and the process of housing privatization was advanced. Unfortunately, the publicly available microdata from the 2011 National Census does not include information on housing. Moreover, Polish national censuses do not provide any information on income other than the income source. Consequently, we turn to the data from the HBSs to examine for whom the public housing sector in Lodz functioned in the second decade after the demise of socialism.

The HBS is conducted by the Central Statistical Office of Poland and collects information on household incomes, expenditure, and on their demographic and socioeconomic characteristics and housing conditions. Approximately 37,000 households in Poland are examined every year. Whereas each round of the survey is representative for Poland, obtaining reliable and representative information for Lodz requires pooling samples from at least two rounds. We then employ the microdata from the following rounds of the HBS: 2003, $2004,2005,2011,2012$, and 2013. Eventually, we pooled the first three HBSs into one data set of 1864 households in total; accordingly, the 2011-2013 surveys were pooled into the other data set of 2001 households in total. The microdata from the HBSs was prepared and provided by the Central Statistical Office. Even though the samples from the HBS are much smaller than the ones from national censuses, they are still representative for Lodz, but the sampling error is approximately $3 \%$. Unlike national censuses, the data contain information on household incomes, and thus allow the process of public housing residualization to be more firmly linked to income stratification in the post-socialist context. Most importantly, the information provided by the HBSs and national censuses allows us to identify the public housing segment that can be directly compared across selected time points (1978, 2002, 2003-2005, and 2011-2013). We then operationalize the notion of public housing stock as the apartments that belong to and are rented from the municipality (gmina) or the state (the State Treasury). Equally important is the fact that the datasets contain information on small territorial units equivalent to census tracts or groups of neighboring tracts in which households reside (the strata variable in the IPUMS data sets or the statistical unit in the HBSs). While it is not possible to locate those tracts in space, the units allow one to control for the spatial residential heterogeneity of Lodz in regression models.

We specify a binominal logistic regression with clustered standard errors to explore who (which social groups) relied on public housing in Lodz under socialism and after. Clustering standard errors allows for correlation between households in the same local neighborhood (or other unit; Cameron \& Miller, 2015). Put differently, if the potential similarity between households in the same tract is not taken into account, estimated results could be biased, as observations are not independent. Then clustering by strata units or statistical units ensures robust estimates of the socio-demographic profile of public housing residents. To avoid extra clustering by households, the analysis is limited to household heads. In each regression model, the dependent variable denotes that a household rents an apartment from the public housing stock; the reference category is all other housing. We separately estimate models for each time point. Importantly, as the set of explanatory variables depends on the data source, only the results of models relying on the data from the same source (national censuses or HBSs) can be directly compared. Despite this limitation, we believe that some general trends in the evolving socio-demographic composition of public housing residents can be distinguished. In trying to select a set of explanatory variables, we isolate the demographic, economic and social characteristics that appear to be significant predictors of housing segmentation and/or housing inequalities under socialism (Kulu, 2003; Szelenyi, 1983), under the post-socialist transition (and after; see Gentile, 2015; Gentile \& Marcińczak, 2014; Hess et al., 2012; Soaita \& Dewilde, 2020; Lux et al., 2011), and in Western Europe (Musterd, 2014; Norris \& Winston, 2012). Accordingly, we select the following 
characteristics of household heads and their households from the national censuses: age, household type, level of educational attainment, and socio-professional category (for 2002 only). Concerning the characteristics available from the HBSs, in addition to the above-mentioned sociodemographic factors, we selected two additional variables: the information on households' monthly incomes (income quintile groups) and on their residential mobility statuses. The latter variable indicates how long a household has resided in the present apartment/house-we consider those that have moved into the present apartment within the last ten years as movers.

\section{Findings}

\subsection{Regression Results}

Table 2, model 1, illustrates the relationship between socio-demographic factors and reliance on public housing in Lodz in 1978. The model is significant and the Nagelkerke pseudo $R^{2}$ (pseudo $R^{2}$ hereafter) is 0.089 . The age of household heads increases the probability of living in public housing. The effect of educational attainment is especially revealing in terms of the link between this segment of housing and social stratification under mature socialism. In fact, public stock housed noticeably lower social categories than the other segments (private and cooperative)-the probability of being a resident in public housing decreases, virtually linearly, along with level of education. Also being employed decreased the probability of residing in this type of housing. Families with children were the least likely, especially if compared with single person households, to reside in public housing. Thus, the effects of selected determinants generally reflect the logic of housing allocation under socialism. Apart from a number of other factors (cf. Gentile \& Sjöberg, 2013), younger families with children and the better educated enjoyed better access to new and higher quality housing (Węcławowicz, 1998; Szelenyi, 1983). From the 1960s until the collapse of the socialist system, the higher quality housing in Poland was offered by state-controlled housing cooperatives, and access to this kind of dwelling required downpayments (Ciechocińska, 1987). Put differently, even if the state owned nationalized and new-build dwellings housed higher social groups in CEE in the first decades of socialism (Chelcea, 2012; Szelenyi, 1983), our results suggest that this segment was already overrepresented

Table 2. Binominal logistic regression models on reliance on public housing, Lodz, 1978 and 2002.

\begin{tabular}{|c|c|c|c|}
\hline \multirow[t]{2}{*}{ Covariate } & \multirow{2}{*}{$\begin{array}{c}1978 \\
\text { Model } 1\end{array}$} & \multicolumn{2}{|c|}{2002} \\
\hline & & Model 2 & Model 3 \\
\hline Constant & $0.967 *$ & $0.245^{* * *}$ & $0.486 * * *$ \\
\hline Age & $1.014 * * *$ & $0.887^{* * *}$ & $0,987 * * *$ \\
\hline \multicolumn{4}{|c|}{ Education (ref: primary or without education) } \\
\hline Vocational & $0.829 * * *$ & 0.973 & $0.935^{\prime}$ \\
\hline Secondary & $0.652 * * *$ & $0.405^{* * *}$ & $0.447 * * *$ \\
\hline Higher & $0.529 * * *$ & $0.205^{* * *}$ & $0.256 * * *$ \\
\hline \multicolumn{4}{|c|}{ Household type (ref: married couple with children) } \\
\hline Single & $3.405^{* * *}$ & $1.046^{\prime}$ & $1.067^{\prime}$ \\
\hline Married couple without children & $1.156 * * *$ & $0.668 * * *$ & $0.682 * * *$ \\
\hline Single parent & $1.435^{* * *}$ & $1.534^{* * *}$ & $1.520 * * *$ \\
\hline Extended family & $1.187^{* * *}$ & $1.431 * * *$ & $1.499 * * *$ \\
\hline Other & $1.662 * * *$ & 1.210 & $1.414^{\prime}$ \\
\hline \multicolumn{4}{|l|}{ Employment status (ref: not working) } \\
\hline Working & $0.739 * * *$ & $0.747^{* * *}$ & \\
\hline \multicolumn{4}{|c|}{ Socioeconomic status (ref: managers, higher clerks) } \\
\hline Professionals & & & $1.352 * * *$ \\
\hline Technicians & & & $1.517^{* * *}$ \\
\hline Clerks & & & $1.773 * * *$ \\
\hline Service workers & & & $1.933 * * *$ \\
\hline Production workers & & & $1.803 * * *$ \\
\hline Machine operators & & & $1.813^{* * *}$ \\
\hline Unskilled workers & & & $2.728 * * *$ \\
\hline Pensioners and retired & & & $2.216 * * *$ \\
\hline Living on social assistance & & & $3.850 * * *$ \\
\hline Other sources of income & & & $2.647 * * *$ \\
\hline Nagelkerke $R^{2}$ & 0.089 & 0.146 & 0.214 \\
\hline$N$ & 23078 & 33567 & 33552 \\
\hline
\end{tabular}

Note: '0.1, ${ }^{*} 0.05,{ }^{* *} 0.01$ and ${ }^{* * *} 0.001$. 
by lower social categories by the late 1970s. Interestingly, the study by Marcińczak and Sagan (2011) suggests that concentrations of public housing were a significant indicator of low social status areas in Lodz in 1988, which means that the position of public housing stock did not improve over the last decade of socialism.

The effect of the selected demographic and socioeconomic predictors on reliance on public housing appears to be stronger in 2002 than in 1978 (Table 2, model 2); as showed by the pseudo $\mathrm{R}^{2}$, the model's explanatory power raises to 0.146 . While the effect of age changed direction after the first decade of transition (the elderly were more likely to rely on the other tenure types than public housing), some differences can also be noticed in the effect of household type on housing segmentation. In fact, only the more socially vulnerable (single parents) and extended families were more likely to concentrate in public housing. More importantly, the relationship between educational attainment of household heads and the likelihood of living in public housing points to further social downgrading of this tenure segmentfor the highly educated, the probability of being a resident in public stock dropped from 0.529 in 1978 to 0.205 in 2002. The results of model 3 (Table 2) provide further insights into the relationship between housing segmentation and socioeconomic stratification ten years after the demise of socialism, and illustrate the process of social decline even more clearly. The adoption of a more detailed classification of socioeconomic groups also raises the explanatory power of the model to 0.214 .
All other factors being constant, socioeconomic status is inversely related to the likelihood of living in public housing in Lodz in 2002; while unskilled workers have an almost three times higher probability of residing in public housing than the highest socio-professional category, for those living on social benefits the probability is nearly four times higher.

The regression analysis on housing segmentation in the 2000s based on the data from the 2003-2005 HBSs generally delivers congruent results with those for 2002 . What is particularly interesting is the effect of household income on residence in public stock (Table 3, model 4). Essentially, even if the lower social categories were overrepresented in public housing, the public sector did not necessarily serve the poorest residents in Lodz in the mid-2000s. There is no significant difference in access to public housing between the first and the second income quintile; however, the population belonging to the third income quintile has nearly two times lower probability of living in public housing. Whereas the effects of education and household structure virtually did not change in the second decade after the fall of socialism, the link between income stratification and housing segmentation became even more clear-cut than in the mid-2000s (Table 3, model 5). More to the point, all income categories have a lower likelihood of residing in public housing than the bottom (lowest) quintile; even the less affluent population, those belonging to the second quintile, are actually half as likely to rely on the public housing sector as those in the lowest income category. For the

Table 3. Binominal logistic regression models on reliance on public housing, Lodz 2003-2005 and 2011-2013.

\begin{tabular}{|c|c|c|}
\hline \multirow[t]{2}{*}{ Covariate } & \multirow{2}{*}{$\frac{2003-2005}{\text { Model } 4}$} & \multirow{2}{*}{$\begin{array}{c}2011-2013 \\
\text { Model } 5\end{array}$} \\
\hline & & \\
\hline Constant & $2.662^{*}$ & $3.625^{* * *}$ \\
\hline Age & $0.985^{* *}$ & $0.979 * * *$ \\
\hline \multicolumn{3}{|c|}{ Education (ref: primary or without education) } \\
\hline Vocational & 0.794 & 1.125 \\
\hline Secondary & $0.488 * * *$ & $0.424 * * *$ \\
\hline Higher & $0.144^{* * *}$ & $0.134 * * *$ \\
\hline \multicolumn{3}{|c|}{ Household type (ref: married couple with children) } \\
\hline Single & 0.605 & $0.584^{*}$ \\
\hline Married couple without children & $0.662^{*}$ & 0.756 \\
\hline Single parent & $1.844^{* *}$ & 1.714 \\
\hline Extended family & $1.665^{* *}$ & $2.950 * * *$ \\
\hline Other & 1.134 & $1.531^{*}$ \\
\hline \multicolumn{3}{|l|}{ Income quintiles (ref: 1st-bottom) } \\
\hline Second & 0.687 & $0.531 * *$ \\
\hline Third & $0.529 * *$ & $0.270 * * *$ \\
\hline Fourth & $0.311 * * *$ & $0.264 * * *$ \\
\hline Fifth (top) & $0.294^{* * *}$ & $0.259 * * *$ \\
\hline \multicolumn{3}{|l|}{ Residential mobility (ref: stayer) } \\
\hline Mover & 1.427 & $0.646 * *$ \\
\hline Nagelkerke $R^{2}$ & 0.202 & 0.220 \\
\hline$N$ & 1864 & 2001 \\
\hline
\end{tabular}

Note: '0.1, ${ }^{*} 0.05,{ }^{* *} 0.01$ and ${ }^{* * *} 0.001$. 
medium and high-income groups, the probabilities of residing in public housing are very similar and they are consistently below 0.3. Put differently, what we observe in the first decade after transition is a firmer relationship between reliance on public housing and income stratification, one that reflects the massive increase in income (and wealth) inequalities in Poland after 1990. Finally, the effect of residential mobility on housing segmentation is statistically significant and points to the fact that the public stock was home to the less residentially mobile population in 2011-2013. The relative residential immobility of those relying on public housing in the early 2010s can be related to the fact that extended families have the highest probability of residing in public housing. Put differently, due to low incomes, it seems that younger generations remain much longer with their families living in public housing than their peers living elsewhere.

\subsection{Changing Quality of Public Housing}

To gain further insights into the process of public housing residualization we also conducted a simple descriptive analysis of the evolving quality of Lodz's public housing stock. Table 4 illustrates the changing levels of housing consumption and sewage provision (the existence of a flush toilet in the dwelling), which are common indicators of housing stratification (Soaita \& Dewilde, 2020). The level of housing consumption was identical in the public and in other housing sectors in Lodz in 1978. This could be the effect of strict housing norms regarding housing consumption under socialism (French, 1995). However, the public housing stock was more disadvantaged than the other segments. This implies that a noticeably lower social status of residents in public housing already coincided with the somewhat lower quality of this housing segment in the late 1970s. Whereas housing consumption increased significantly over the three decades, the process was less advanced in the public housing segment. A gap of approximately six square meters had already emerged between public housing and the other forms of tenure in the early 2000s. More importantly, contrary to the other housing segments, the issue of sewage provision in the public sector did not improve, or even worsened slightly after 1978. Consequently, one in four public dwellings could be labelled as substandard in 2011-2013.

The unique information from the 2011-2013 HBSs additionally offers the opportunity to explore how the residents of public housing evaluate the quality of their dwellings and neighborhoods. The differences in perceived living conditions between the residents of public housing and those relying on other tenure are actually substantial (Table 5). One in three residents in public housing considers the dwelling they occupy to be in poor physical condition and/or cramped. Those who rely on public stock also seem to live in 'bad' areas more often: One-third of them reported living in neighborhoods with a high rate of crime and social problems, and nearly onefourth of them consider their local environment to be polluted. For the population living in the other housing sectors, the share of those who reported living in an unfavorable location is roughly three times smaller. To sum up, the results show that the public housing sector in Lodz is not only more likely to be located in 'problematic' neighborhoods, but also tends to be of low quality.

\section{Conclusion}

The aim of this article was to investigate the pace and effects of public housing residualization in a former socialist city. As elsewhere in West Europe (Kadi \& Ronald, 2014) and in CEE (Lux \& Sunega, 2014), the decline of the public housing sector in Poland is an undeniable fact. However, our findings from Lodz suggest that

Table 4. Housing consumption and housing disadvantage in Lodz, 1978-2013.

\begin{tabular}{lllllllll}
\hline & \multicolumn{2}{c}{1978} & \multicolumn{2}{c}{2002} & \multicolumn{2}{c}{ 2003-2005 } & \multicolumn{2}{c}{ 2011-2013 } \\
\hline Housing tenure & Other & Public & Other & Public & Other & Public & Other & Public \\
Living area per capita in $\mathrm{m}^{2}$ & 17.75 & 17.78 & 26.26 & 19.17 & 26.12 & 20.45 & 30.79 & 24.73 \\
Flush toilet in dwelling (in \%) & 82.2 & 77.3 & 94.9 & 76.4 & 93.3 & 70.3 & 98.0 & 73.4 \\
\hline
\end{tabular}

Table 5. Self-evaluation of living conditions, Lodz, 2011-2013.

\begin{tabular}{lcc}
\hline Housing tenure & Public & Other \\
\cline { 2 - 3 } & Positive answers (in \%) \\
\hline Has your dwelling leaky roof, damp walls, floors, foundations, rotting windows and floors? & 33.7 & 7.1 \\
Is your dwelling cramped and/or does it not have enough sunlight? & 29.3 & 8.2 \\
Is your dwelling located in a polluted environment (dust, smoke, other sources of pollution)? & 24.5 & 3.2 \\
Is your dwelling located in a dangerous neighborhood (high crime rate, vandalism, & 33.7 & 11.3 \\
social problems) &
\end{tabular}


some context-specific characteristics of the process can be distinguished. The process of public housing residualization in Lodz, apart from the steady shrinkage of this form of tenure, manifests itself in two ways.

First, our results show that the process of give-away privatization is selective and sensitive to differences within public housing stock, and involves increasing housing disadvantage rates in the public sector. Put differently, there is less and less public housing, and what is left is in very poor physical condition. The relatively high rate of housing disadvantage in the public sector could be explained by the development path and specific urban structure of Lodz. The parts of the city constructed before 1945 are very densely built-up with predominantly low-quality tenements, and pre-socialist housing was nationalized under socialism thus becoming the backbone of the public stock. As the efforts of the socialist state concentrated on new housing developments, pre-socialist dwellings were not renovated. The good quality public housing in the blocks of flats on housing estates was privatized first. Due to unresolved issues with property rights, give-away privatization has been less smooth in the historical core. While the high-quality tenements inhabited by higher social categories under socialism (Marcińczak \& Sagan, 2011) were equally likely to be privatized or returned to former owners or their heirs, a relatively large housing stock of (very) low quality dwellings remained in public hands. The poor economic condition of the city in the first decade after 1990 and the lack of subsidies from central government for housing maintenance (the decentralization paradox (Lux \& Sunega, 2014)) did not improve the position of the public housing sector in the city. The residents of lowquality public dwellings were often recruited from the lower social categories and usually preferred keeping low rents rather than becoming poor owners.

Second, the evolving socioeconomic composition of public housing residents unequivocally points towards declining social status. However, contrary to what is often assumed (Hegedus et al., 2013), public housing was not already primarily serving the socialist 'middle class' in the late 1970s. It then appears that the first signs of residualization can already be identified back then, and there is convincing empirical material suggesting that the process continued in the late socialist era (Marcińczak, Gentile, \& Stępniak, 2013). This was the result of constant shortages under socialism (Kornai, 1992) and the development of cooperative housing for those who could participate in the construction costs (Ciechocińska, 1987). Interestingly, the results from Lodz imply that public housing residualization in the socialist regime began pretty much at the same time as in the more liberal welfare regimes in Europe, the UK in particular (Williams et al., 1988). Put differently, contrary to what is often assumed (Kadi \& Ronald, 2014; Lux \& Sunega, 2014) our findings support the argument that the process of residualization is not necessarily linked with privatization. Even if the process of public housing residualization was already advanced in the early 2000s, it gained momentum in the second decade after transition. Then, after 20 years of systemic social and economic changes, the patterns of housing segmentation are firmly related to the patterns of income stratification, and public housing is generally the stronghold of the worse-off. Accordingly, it is tempting to propose that, similar to the development of social segregation patterns after socialism (Marcińczak et al., 2016), the pace of the residualization process lagged the increase in income inequality, which had already sky-rocketed in the 1990s (Blanchet et al., 2019).

Housing stratification is among the most visible aspects of income and wealth inequality. Regarding the relationship between housing change and the development of economic inequality after socialism, give-away privatization brought about an unprecedented transfer of wealth that generally fossilized socialist-era socioeconomic inequality (Bodnar, 1996; Lux \& Sunega, 2014). Assuming that the lower social categories were already overrepresented in public housing under socialism, it seems that the residents who stayed in public housing after 1990 are doubly disadvantaged. They did not benefit from the post-socialist transition of wealth and, due to their education and skills, often belong to the low-income categories. This in turn implies that they simply lack resources (both incomes and housing that could be commodified) to improve housing conditions and have become trapped in the low-quality public housing sector. The fact that the remaining public housing in Lodz is relatively often located in impoverished and dangerous neighborhoods further adds to the disadvantaged position of those who rely on this housing sector. Importantly, the residual public housing in the innercity was a good indicator of the enclaves of poverty in Lodz in the 1990s (Warzywoda-Kruszyńska \& GrotowskaLeder, 1996). The lack of opportunities to leave those clusters of public housing has had a profound impact on residents' life trajectories. There are concrete results illustrating that children from the poverty enclaves have much lower educational outcomes compared to those from other neighborhoods, and are more prone to delinquency; in fact, poverty and reliance on social welfare (including housing) have often been 'inherited' in families that are stuck in those tracts (Warzywoda-Kruszyńska \& Jankowski, 2013).

This study clearly shows that public housing residualization is a path-dependent process, and its effects are context-specific. But our analysis, like many previous studies (Gentile, 2015; Gentile \& Marcińczak, 2014; Hess et al., 2012), is limited to only one case. Consequently, assuming that cities differ not only in morphology, functional specialization, and exposure to globalization, but also in housing policies adopted and approaches to public housing, we suggest that future studies should investigate the process of public housing residualization in the comparative perspective encompassing a larger number of cities, preferably from different housing systems 
(Stephens et al., 2015). We believe that comparative studies should allow a better understanding of how public housing residualization unfolds in different spatial and institutional settings and is co-determined by the local context. This in turn can be helpful in identifying those conditions that can potentially reduce the most negative effects of residualization. Regarding potential policy implications for Lodz, the city should continue with the more selective privatization that was introduced in the early 2010s. More precisely, the municipality should concentrate on the improvement of the technical condition of those buildings in the inner-city where all apartments belong to the public sector; by the same token, the municipality should privatize the apartments in buildings where only a small share of apartments is public housing. Finally, to reduce the concentration of poverty in residualized public housing, especially old tenements, along with the regeneration of housing stock, some forms of social mixing should be considered when distributing renovated public housing.

\section{Acknowledgments}

This work was supported by National Center for Science of Poland (UMO-2016/23/G/HS4/01572). We thank three anonymous referees for their excellent comments on the article.

\section{Conflict of Interests}

The authors declare no conflict of interests.

\section{References}

Benjamin, J., Chinloy, P., \& Jud, G. (2004). Why do households concentrate their wealth in housing? The Journal of Real Estate Research, 26(4), 329-344.

Blanchet, T., Chancel, L., \& Gethin, A. (2019). How unequal is Europe? Evidence from distributional national accounts (Working Paper No. 2019-06). Paris: World Inequality Lab. Retrieved from https:// wid.world/document/bcg2019-full-paper

Bodnar, J. (1996). 'He that hath to him shall be given': Housing privatization in Budapest after state socialism. International Journal of Urban and Regional Studies, 20(4), 616-636.

Brenner, N., Peck, J., \& Theodore, N. (2010). Variegated neoliberalization: Geographies, modalities, pathways. Global Networks, 10(2), 182-222.

Cameron, A., \& Miller, D., (2015). A practitioner's guide to cluster-robust inference. The Journal of Human Resources, 50(2), 317-372.

Chelcea, L. (2012). The 'housing question' and the state socialist answer: City, class and state remaking in the 1950s Bucharest. International Journal of Urban and Regional Research, 36(2), 281-296.

Ciechocińska, M. (1987). Government interventions to balance housing supply and population growth: The case of Warsaw. International Journal of Urban and Regional Research, 11(1), 9-26.

City Hall of Lodz. (2012). Polityka mieszkaniowa Łodzi 2020+ [Lodz housing policy 2020+] (Resolution XLIV/825/12). Lodz: City Hall.

Criman, A. (2008). Intergenerational transfers as a response to changes in the housing market in Slovenia. European Journal of Housing Policy, 8(3), 303-315.

Forrest, R. (2014). Public housing futures. Housing Studies, 29(4), 463-466.

Forrest, R., \& Murie, A. (1983). Residualization and council housing: Aspects of the changing social relations of housing tenure. Journal of Social Policy, 12(4), 453-468.

Forrest, R., \& Williams, P. (2001). Housing in the twentieth century. In R. Paddison (Ed.), Handbook of urban studies (pp. 88-101). London: SAGE.

French, A. (1995). Plans, pragmatism and people. London: UCL Press.

Gentile, M. (2015). The "Soviet" factor: Exploring perceived housing inequalities in a midsized city in the Donbas, Ukraine. Urban Geography, 36(5), 696-720.

Gentile, M., \& Marcińczak, S. (2014). Housing inequalities in Bucharest: Shallow changes in hesitant transition. GeoJournal, 79, 449-465.

Gentile, M., \& Sjöberg, Ö. (2013). Housing allocation under socialism: The soviet case revisited. Post-Soviet Affairs, 29(2), 173-195.

Hegedus, J., Lux, M., \& Teller, N. (Eds.). (2013). Social housing in transition countries. London and New York, NY: Routledge.

Hegedus, J., \& Tosics, I. (1998). Rent reform-Issues for countries of eastern Europe and the newly independent states. Housing Studies, 13, 657-658.

Hess, D., Tammaru, T., \& Leetmaa, K. (2012). Ethnic differences in housing in post-Soviet Tartu Estonia. Cities, 29(5), 327-333.

Kadi, J., \& Ronald, R. (2014). Market-based housing reforms and the 'right to the city': The variegated experiences of New York, Amsterdam and Tokyo. International Journal of Housing Policy, 14(3), 268-292.

Kemeny, J. (1995). From public housing to the social market: Rental policy strategies in comparative perspective. London: Routledge.

Kornai, J. (1992). The socialist system. Princeton, NJ: Princeton University Press.

Kulu, H. (2003). Housing differences in the late soviet city: The case of Tartu, Estonia. International Journal of Urban and Regional Research, 27(4), 897-911.

Lux, M., \& Sunega, P. (2014). Public housing in the postsocialist states of Central and Eastern Europe: Decline and an open future. Housing Studies, 29(4), 501-519.

Lux, M., Sunega, P., \& Katrňák, T. (2011). Classes and castles: Impact of social stratification on housing inequality in post-socialist states. European Sociological Review, 29(2), 274-288. 
Madden, D., \& Marcuse, P. (2016). In defense of housing: The politics of crisis. London and New York, NY: Verso Books.

Marcińczak, S., Gentile, M., \& Stępniak, M. (2013). Paradoxes of (post)socialist segregation: Metropolitan sociospatial divisions under socialism and after in Poland. Urban Geography, 34(3), 327-352.

Marcińczak, S., Musterd, S., \& Stępniak, M. (2012). Where the grass is greener: Social segregation in three major Polish cities at the beginning of the twenty-first century. European Urban and Regional Studies, 19(4), 383-403.

Marcińczak, S., Musterd, S., van Ham, M., \& Tammaru, T. (2016). Inequality and rising levels of socio-economic segregation. Lessons from a pan-European comparative study. In T. Tammaru, S. Marcińczak, M. van Ham, \& S. Musterd (Eds.), Socio-economic segregation in European capital cities: East meets West (pp. 358-382). London and New York, NY: Routledge.

Marcińczak, S., \& Sagan, I. (2011). The socio-spatial restructuring of Lodz Poland. Urban Studies, 48(9), 1789-1809.

Milewska, K., \& Ogrodowczyk, A. (2006). Struktura budownictwa wielorodzinnego na obszarze Łodzi [Structure of multi-family housing in Lodz]. Biuletyn KPZK, 227.

Minnesota Population Center. (2020). Integrated public use microdata series, international: Version 7.3 (Poland 1978) [Data set]. https://doi.org/10.18128/ D020.V7.3

Murie, A. (1997). The social rented sector, housing and the welfare state in the UK. Housing Studies, 12(4), 437-461.

Musterd, S. (2014). Public housing for whom? Experiences in an era of mature neo-liberalism: The Netherlands and Amsterdam. Housing Studies, 29(4), 467-484.

Norris, M., \& Winston, N. (2012). Home-ownership, housing regimes and income inequalities in Western Europe. International Journal of Social Welfare, 21(1), 127-138.

Ogrodowczyk, A. (2014). Polityka mieszkaniowa a współczesne przekształcenia obszarów śródmiejskichPrzykład Łodzi [Housing policy and contemporary changes of the inner city-The example of Lodz]. Prace Naukonwe Uniwersytetu Ekonomicznego we Wrocławiu, 367, 232-239.

Ogrodowczyk, A. (2015). Spatial aspects of housing policy transformation in Poland after 1989-Example from
Lodz. Journal of Economics and Management, 19(1), 137-154.

Republic of Poland. (1990). Local Government Act (Journal of Laws, No. 16, item 95). Warsaw: The Council of Ministers

Soaita, A. M., \& Dewilde, C. (2019). A critical-realist view of housing quality within the post-communist EU states: Progressing towards a middle-range explanation. Housing, Theory and Society, 36(1), 44-75.

Soaita, A. M., \& Dewilde, C. (2020). Housing stratification in Romania: Mapping a decade of change. Journal of Housing and the Built Environment. Advance online publication. Retrieved from https://doi.org/10.1007/ s10901-020-09788-8

Stephens, M., Lux, M., \& Sunega, P. (2015). Post-socialist housing systems in Europe: Housing welfare regimes by default? Housing Studies, 30(8), 1210-1234.

Struyk, R. J. (1996). Economic restructuring of the former Soviet bloc: The case of housing. Washington, DC: Urban Institute Press.

Szelenyi, I. (1983). Urban inequalities under state socialism. New York, NY: Oxford University Press.

Turner, B., Hegedus, J., \& Tosics, I. (1992). The reform of housing in Eastern Europe and the Soviet Union. London: Routledge.

Uchman, R., \& Adamski, J. (2003). How to meet the market rules and social goals for housing? Local government and housing in Poland. In M. Lux (Ed.), Housing policy: An end or a new beginning? (pp. 120-181). Budapest: Local Government and Public Service Reform Initiative, Open Society Institute.

Warzywoda-Kruszyńska, W., \& Grotowska-Leder, J. (1996). Wielkomiejska bieda w okresie transformacji (zasiłkobiorcy pomocy społecznej) [Urban poverty during transformation (beneficiaries of social assistance)]. Lodz: Instytut Socjologii UŁ.

Warzywoda-Kruszyńska, W., \& Jankowski, B. (2013). Ciągłość i zmiana w łódzkich enklawach biedy [Continuity and change in the enclaves of poverty in Lodz]. Lodz: Wydawnictwo Uniwersytetu Łódzkiego.

Węcławowicz, G. (1998). Social polarisation in post socialist cities: Budapest, Prague and Warsaw. In G. Enyédi (Ed.), Social change and urban restructuring in central Europe (pp. 55-66). Budapest: Akadémiai Kiadó.

Williams, N. J., Sewel, J. B., \& Twine, F. E. (1988). Council house sales: An analysis of the factors associated with the purchase and implications for the future of public sector housing. Tijdschrift voor Economische en Sociale Geografie, 79, 39-49.

\section{About the Authors}

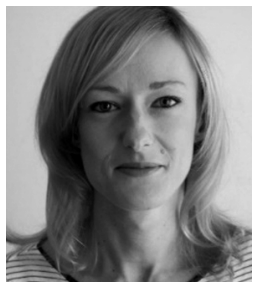

Agnieszka Ogrodowczyk is an Assistant Professor at the Institute of the Built Environment and Spatial Policy, University of Lodz (Poland). Her areas of scientific interest include social and spatial implications of housing policy, housing inequalities in urban areas, as well as contemporary changes of the inner cities, related to the revitalization and gentrification. Her recent research involves building an urban resilience in the shrinking cities. 


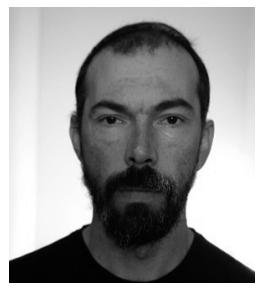

Szymon Marcińczak is an associate professor at the Institute of Urban Geography, Tourism Studies and Geoinformation, University of Lodz (Poland). Marcińczak is an Urban Geographer with an interest in socioeconomic inequality, segregation, and urban change. He has been primarily involved in studies on the links between systemic political, social, and economic changes and evolving patterns of social segregation. More recently, he was engaged in research on immigrants (spatial) integration in different domains of everyday life. 